\title{
An Analysis of Opportunities for Sharia (Syariah) Transaction Implementation at BUMNag in Tanah Datar Regency
}

\section{Nasfizar Guspendri, Sri Adella Fitri, and Elfina Yenti}

FEBI IAIN BATUSANGKAR

\section{Abstract}

Tanah Datar regency is as an area that uses the philosophy of 'adat basandi syarak, syarak basandi kitabullah (ABS-SBK)', so that this philosophy requires society to run everything according to the philosophy that is based on 'Al-quran' and hadith. In an effort to realize this philosophy, the local government urges all villages (nagari) to be able to make it happen in the form of economic transactions that are not contrary to the teachings of Islam. BUMNag is one of the right containers to apply the

Corresponding Author: Nasfizar Guspendri nasfizar@iainbatusangkar.ac.id

Received: 25 February 2018 Accepted: 26 May 2018 Published: 26 June 2018

Publishing services provided by Knowledge $\mathrm{E}$

(c) Nasfizar Guspendri et al. This article is distributed under the terms of the Creative Commons

Attribution License, which permits unrestricted use and redistribution provided that the original author and source are credited.

Selection and Peer-review under the responsibility of the ICIFEB Conference Committee.

\section{G OPEN ACCESS} principles of sharia (syariah), for example, in the form of Islamic financing and sharia (syariah) products. But in reality, BUMNag that already exist in Tanah Datar regency still runs the conventional principle. This research was a field research, qualitative paradigm. The techniques of data collection were interviews and documentation. In-depth interviews were conducted of the BUMNag managers and villages. And, the community figures were taken as samples (as informants). The results of this study indicated that Tanah Datar regency has a great opportunity to develop the principles of sharia (syariah) in accordance with the philosophy used in Tanah Datar regency 'ABS-SBK'.

\section{Keywords: BUMNag}

\section{Introduction}

\subsection{Background of the problem}

The National Law No. 6 of 2014 about villages promotes villages as a force that will contribute to the advancement of a country that starts from the smallest government. High attention has been given by the government to the village in the hope that the village development will improve the welfare of the community with the fulfillment of basic needs of life for the village community. 
Acceleration of self-sufficiency and welfare in rural areas requires a series of planned and structured activities and programs for the management of the village's fund allocations. In this case, it is deemed necessary to establish a Village-owned Enterprise (Badan Usaha Milik Desa/BUMDes) in order to manage and coordinate funds efficiently and effectively. This BUMDes is also one of the government programs to shape the welfare of society both in education-social and religion-and economy. The BUMDes is expected to minimize the poverty rate in Indonesia. In accordance with the Village Law, Article 87, all purposes of village development can be realized through the establishment of BUMDes.

BUMDes is a venue for village governance and citizens, and has a role in realizing the improvement of people's welfare through the development of various local economic potentials that can be empowered as a form of community economic development. BUMDes stands in accordance with the needs and potential of the village, the various development of BUMDes can be developed. The potential of each village greatly contributes to the development of BUMDes.

Tanah Datar regency which is part of West Sumatra province, a very strong regency with its Minangkabau custom, has 14 sub-regencies with 75 villages (nagari). The term 'villages' (nagari) is a reference to the existing rural areas of West Sumatra, including Tanah Datar regency, villages are called 'nagari', therefore, village-owned enterprises (BUMDes) in Tanah Datar regency are called Nagari-owned Enterprises (BUMNag).

The local government of Tanah Datar regency is now very serious in making nagari as an independent region and wealth. This is reflected by the issuance of Local Regulation No. 5 in Year 2016, concerning the establishment, management and dissolution of the State-owned Enterprises, abbreviated to BUMNag, where the 'nagari' government is granted the right to determine what type of business will be run in BUMNag in accordance with its own potential for carrying out business. In addition, there has also been socialization to the government of 'nagari' about BUMNag itself.

The government declared that every 'nogari' in the regency of Tanah Datar in 2017 has owned BUMNag, as in the speech of the regent on the opening of Socialization of Tanah Datar Regency Regulation No. 5 of 2016 on BUMNag in the office hall of Pagaruyung Regency which said that of 75 villages in Tanah Datar in 2017, it is expected to have BUMNag, for funding is urged to each 'nagari' to budget in the preparation of 'RKP' and 'APB' nogari in 2017.

Tanah Datar regency community is a religious community that upholds the values of Islamic religion in carrying out daily life; it is in line with the traditional philosophy of Minangkabau which has become the local wisdom of the community itself, namely 
'adat basandi syarak, syarak basandi kitabullah (ABS-SBK)', in the sense that the community is interacting and transacting or running it in accordance with the rules and traditions and customary law where custom is appropriate and refers to the teachings of Islam.

Nogari who already owns BUMNag in its management and finance still runs business with conventional system, among BUMNag activities is to provide interest-based savings and loan services. Obviously, this is a ribawi transaction that has violated the rules of Islamic sharia.

The management and financing made by the existing BUMNag of some nagari governments in the Tanah Datar regency still run the conventional system that is indicated by the element of usury. This is certainly contrary to the 'ABS-SBK' philosophy that became the typical culture of people living in Minangkabau region. Transactions with the usury (riba) system is seen to cause negative impact, the existence of the wrongdoer in the transaction, the owners of capital will be over-capitalized distress people who need capital. This contributes to the fact that people are not interested to use BUMNag as a business partner, or their place to do the financing.

To solve the aforementioned problem, there needs to be a review of the implementation of financing and financial management of BUMNag which synergize with the objective of the allocation of village funds to improve the welfare of the community based on mutual help and mutual assistance, and in harmony with the local ABS-SKB strongly held by the Minangkabau community. Attributed to the 'syarak besandi kitabullah (ABS-SBK)' in the management and financing actually this can be said to make the concepts and principles of sharia (syariah) economy and financing that therein as a reference and reference, whether from within the management, BUMNag business products and accountability. Human resources should also reflect the behavior and ethics that are in accordance with Islamic sharia.

\section{Review of the Related Literature}

\subsection{The concept of village}

The village is the smallest unit of government within the scope of governance in Indonesia (Gunawan sumodiningrat, p.13). Law No. 6 of Year 2014 regarding the village declares that the village is a village and a custom (adat) village or called by another name, hereinafter referred to as the Village (desa), is a legal community unity that has territorial boundaries to administer and administer government affairs, the interests 
of local communities based on community initiatives, origin, and/or traditional rights recognized and respected in the government system of the Republic of Indonesia. According to Article 6 of Law No. 6 of Year 2014, the village consists of 'Desa' and 'Desa Adat'.

Elucidation of Law No. 6 of Year 2014 states that the Village or other so-called name has general characteristics for the whole of Indonesia, whereas 'Adat' Village or other named has different characteristics from the village in general, mainly because of the strong influence of adat to the local governance system, the management of local resources and the sociocultural life of the village community.

\subsection{Village-owned enterprise}

In order to increase the income of villagers and villages, the village government (Desa) can establish a village-owned enterprise in accordance with the needs and potential of the village, namely:

1. the needs of the community, especially in the fulfillment of basic needs,

2. the available village resources that have not been utilized optimally, especially the village's wealth,

3. the available human resources capable of managing the enterprise as an asset driving the community economy,

4. the existence of community business units that are economic activities of the community that are managed in a pasial and less accommodated manner, which in the form of law can be a business institution, that is, a business unit whose share ownership comes from the village government and society, such as micro, small- and medium enterprises, micro rural (savings and loan village economic enterprise, village credit agency, granary pitih nagari, etc.), and stipulated in village regulations based on Regency/City Regulations and legislation.

Village-owned Enterprises are Village Businesses. Types of business that includes village economic services are:

1. business that includes financial services, land and water transportation services, village electricity and other similar enterprises,

2. channeling nine basic economic goods of the village, 
3. trading of agricultural products including crops, plantations, farms, fisheries and agribusiness administered by the village government, whose stewardship consists of the village government and the community as operational elements and their capital may come from:

4. village government (equity participation from village wealth),

5. community savings,

6. government assistance, provincial and regency/city governments,

7. loans and

8. participation of other party's equity or profit-sharing cooperation on the basis of mutual benefit.

Further provisions concerning the procedures for forming and managing a Villageowned Enterprise are regulated by a Regency/City Regulation, which in the regulations shall at least contain:

1. Form of legal body

2. Stewardship

3. Rights and obligations

4. Capital

5. Profit sharing

6. Cooperation with third parties

7. Mechanism of management and accountability.

This can be seen from the following chapters:

\section{Article 143}

1. Village cooperation shall be conducted between villages and/or with third parties.

2. Implementation of inter-village cooperation shall be regulated by the village head.

3. Implementation of village cooperation with third parties shall be regulated by collective agreement. 
4. The joint rules and collective agreements as referred to in paragraph (2) and paragraph (3) shall at least contain:

5. Scope of cooperation;

6. Field of cooperation;

7. Procedures and conditions of implementing cooperation;

8. Time period;

9. Rights and obligations;

10. Funding;

11. Procedures for change, delays and cancellations; and

12. Dispute resolution.

13. The sub-Regency head (Comat) or other designation on behalf of the regency governor (Bupati)/ mayor facilitates the implementation of inter-village cooperation or village cooperation with third parties.

\section{Article 137}

1. To develop business activities BUM Desa can:

a. Receive legitimate loans and/or assistance from other parties; and

b. establish a BUM Desa business unit.

2. The village BUM that undertakes the loan must obtain the approval of the Village Government.

3. The establishment and management of the BUM Desa business unit as referred to in paragraph (1) shall be conducted in accordance with the provisions of the law.

\section{Article 138}

1. The operational implementation in managing the Village business represents BUM Desa inside and outside the court.

2. Operational implementation shall report the responsibility of management of BUM Desa to the village head periodically. 


\section{Article 139}

The losses experienced by the village BUM is the responsibility of the operational implementer of the village BUM.

\subsection{The theory of regency and village reports}

\subsubsection{Regency and village reports}

Reports are defined as documents that contain organized information in a narrative, graphic or tabular form prepared on an ad-hoc basis, periodically, routinely or when required. Reports may refer to specific periods, events, or subjects and may be communicated or presented in written oral form. Sub-Regency public reports shall mean documents containing such information in relation to development undertaken in the sub-Regency and village concerned (Indra Bastian, p.337).

Village head (kepala desa) is the holder of village finance management (V. Wiratna Surjarweni, p.30). In carrying out the duties, authorities, rights and obligations as mandated in Article 26, the village head shall:

1. submit reports on the implementation of Village Governance at the end of the fiscal year to the regency governor (Bupati)/Mayor;

2. submit reports on the implementation of Village Government at the end of the term of office to the regency governor (Bupati)/Mayor;

3. provide a written statement of the governmental administration to the Village Consultative Board at the end of the fiscal year; and

4. provide and/or disseminate information on the administration of the government in writing to the village community at the end of the fiscal year (Law No. 6 of Year 2014 About Villages).

\subsubsection{Main duty reporting environment in Kecamatan}

Sub-Regency (Kecomaton) reports are a form of presentation of facts about a situation or development activities undertaken in the Regency concerned. Basically, the facts presented were pleased with the responsibilities given to the reported sub-Regency organizations. Because the main task of the sub-Regency is as coordinator or synergy of the development process in the villages within the sub-Regency, the scope of this 
sub-Regency report is the implementation of the program and the achievement of the main duties of the sub-Regency. The facts presented are material or information based on the objective circumstances of the sub-Regency condition that they want to report.

The sub-Regencys' main task report was initially only a tool for examining bookkeeping work, but it was also used as a basis for determining or assessing the condition of the sub-Regency required by the sub-Regency organization as a whole to assess the achievements and possible outcomes to be achieved in the future.

\subsubsection{Scope of the main duties report in the village}

The report of the main task of the village is a form of presenting the facts about a situation or development activities undertaken in the village concerned. Basically, the facts presented relate to the responsibilities given to the village organizations that report.

\subsection{Sharia (Syariah) contracts-related financial instruments}

Literally, the word 'aqd' (contract) comes from the Arabic verb 'aqada', which means binding, formalizing or ratifying. Muhammad Abu Zahrah defines 'oqd' as a relationship between two sayings (the contracting parties), from which a legal judgment arises on one or both parties.

A valid Sharia (Syariah) contract is structured on the basis of three essential elements: contracts, contractual objects and contracting parties. These essential elements must be fully satisfied in order for a contract to be eligible until its predetermined legal effects, such as the interest and granting of the right to sell/purchase.

The form of the contract refers to statements made by contracting parties in order to declare their inner will to seek a contract, and thereafter be bound by certain obligations. This statement is manifested in the form of an offer (ijab) made by the party offering and receipt (qabul) made by the offered party.

The methods of supply and acceptance are held in the form of words, because the will of the contracting parties can be marked through the expression of their own words. However, the way of bidding and receiving is not limited to speech, because it can also be organized with other methods recognized according to Sharia (Syariah), such as behavior, writing and gestures.

In order for a contract to be concluded to be valid, the jurists have already set three conditions. The terms of supply and acceptance in question are: 
1. clear indication of dispensing and acceptance,

2. the link between dispensing and receiving and

3. the continuity of exposure and acceptance.

\section{Research Methodology}

This research was a field research at the villages in Tanah Datar Regency in which primary data were collected through interview and documentation. Thereafter, the data were analyzed through qualitative analysis. The technique used to analyze the data was in-depth interviews of BUMNag managers, 'nagari' devices and community leaders who were taken as informants.

\section{Discussion}

\subsection{The condition of BUMNag in Tanah Datar regency}

BUMNag determination based on the potential development of the village can be one way to improve the welfare of the 'nagari' community and can increase the original income of the nagari in the future. Because BUMNag is a manifestation of the involvement and participation of the community in order to improve the development of 'nagari' so that it is to improve the welfare of the community.

Even with the implementation of BUMNag in the management and financing, businesses are being run with conventional system. Among other things, BUMNag is required to provide interest-based savings and loan services. Obviously, this is a usury (riba) transaction that has violated the rules of Islamic Sharia (Syariah).

Management and financing undertaken by the existing BUMNag, partly 'nagari' government, in Tanah Datar regency still run the conventional system, which syndicated with the element of usury is certainly contrary to the philosophy of 'Adat Basandi Sarak - Sarak Basandi Kitabullah', which has become a distinctive culture of the people who live in the region of Minangkabau. Transactions with the usury (riba) system is seen to cause negative impact, the existence of the wrongdoer in the transaction, the owners of capital will be over-capitalized distress people who need capital. This can make people not interested to use BUMNag as a business partner, or their place to do the financing. 


\subsection{Opportunity of BUMNag Syariah in Tanah Datar regency}

The amount of potential 'nagari' that can be developed with the formation of BUMNag add public interest that the existence of BUMNag should be in accordance with the principle of 'Adat Basandi Syarak-Syarak Basandi Kitabullah'. All components of the community, ranging from government apparatus nagari, stakeholders, even ordinary people want BUMNag in line with the provisions of Islamic law, so that all activities of transactions can be carried out free from ribawi element. This means that BUMNag opportunity to be developed with the principles of sharia is very wide open in line with the principles of local culture that brings 'ABS-SBK' is very animating people Minangkabau.

The development of BUMNag in the future is very possible to develop various sharia transaction patterns/contracts in accordance with the sharia model that can be developed in the future.

\section{Conclusion}

The management of BUMNag is still conventional, where the transaction still contains interest and includes ribawi element. The amount of opportunity developed by BUMNag with the principles of shariah with local wisdom in accordance with the principle of 'ABS-SBK' can stimulate the development of sharia (Syariah) contract patterns in the future.

\section{Suggestion}

For the next research, it is suggested to develop the model of sharia contract in BUMNag in Tanah Datar Regency.

\section{References}

[1] Gunawan Sumodiningrat. Membangun Indonesia dari Desa, Cetakan I. Media Pressindo, Yogyakarta, 2016.

[2] Hanny Purnamasari, Eka Yulyana, Rachmat Ramdani. Efektivitos Pengeloloan Badan Usaha Milik Desa (BUM Desa) Berbasis Ekonomi Kerakyaton di Desa Warung Bambu Kecamatan Kerawang Timur Kabupaten Kerawang. No. e-ISSN: 2528 - 2069). 
[3] Indra Bastian. Akuntansi untuk Kecamaton dan Desa. PT. Gelora Aksara Pratama, Jakarta, 2014.

[4] Peraturan Bupati Tanah Datar Nomor 5 tahun 2016 tentang Pedoman Pendirian, Pengurusan, Pengelolaan dan Pembubaran Badan Usaha Milik Negara.

[5] Peraturan Menteri Desa, Pembangunan Daerah Tertinggal dan Transmigrasi Republik Indonesia No. 1 tahun 2015 tentang Kewenangan Berdasarkan Hal Asal Usul Desa dan Kewenangan Lokal Berskala Desa.

[6] Undang-Undang Nomor 6 Tahun 2014 tentang Desa.

[7] V. Wiratna Sujarweni. Akuntansi Desa Panduan Tata Kelola Keuangan Desa. Pustaka Baru Press, Yogyakarta, 2015. 